\title{
WATSON'S CATEGORIES ANALYSIS OF SEQUENCES AND SERIES QUESTION
}

\author{
Anggita Maharani*1, Ika Wahyuni ${ }^{2}$, Cucu Oktavianingsih ${ }^{3}$ \\ ${ }_{1,2,3}$ Universitas Swadaya Gunung Djati
}

\section{Article Info \\ Article history: \\ Received Jan 15, 2019 \\ Revised Jan 26, 2020 \\ Accepted Jan 30, 2020}

\section{Keywords:}

Error categories,

Sequence and series,

Watson

\begin{abstract}
This article contains students' answers to the row and series questions which are then analyzed based on the Watson category. The problem that often arises is a large number of students who still cannot give the right answer to the sequence and sequence problems. Analysis very important to do, especially on the wrong answers so that the teacher knows where the student lies in solving a problem so the teacher can take appropriate corrective action. The Watson category is used to facilitate the tracking of errors that are often made by students. This paper describes the types of errors in solving row and series problems based on the Watson category and describes the percentage of each type of error. This type of research is a descriptive study with a qualitative approach. This research was conducted by giving a test about sequences and series question in the form of a description of four questions. The results showed that there were two categories based on Watson which were dominantly carried out by students, namely 1 ) incorrect procedures (34.06\%) and 2) conclusions were lost (20.33\%).
\end{abstract}

Copyright $(2020$ IKIP Siliwangi. All rights reserved.

Corresponding Author:

Anggita Maharani,

Department of Mathematics Education,

Universitas Swadaya Gunung Djati

Jl. Pemuda Raya No.32, Kesambi, Cirebon, West Java 45132, Indonesia

Email: anggi3007@yahoo.co.id

\section{How to Cite:}

Maharani, A., Wahyuni, I., \& Oktavianingsih, C. (2020). Watson's categories analysis of sequences and series question. Infinity, 9(1), 31-40.

\section{INTRODUCTION}

Children are provided with mathematics as early as possible from kindergarten to high school and even college. Mathematics are able to solve problems (Ratnasari, Rosita, \& Pramuditya, 2017). Through line and line material learning, students are expected to be able to think at a high level to solve a problem.

The results of observations showed that in the row and series material there were still many students who made mistakes solving the problems. In general, students feel confused if the test is given a slightly different problem when studying in class. Students feel difficulties in the use of formulas between arithmetic and geometry. One of the problems is determining the middle term of arithmetic lines $6,9, \ldots, 36$. One student answer can be seen in Figure 1. 


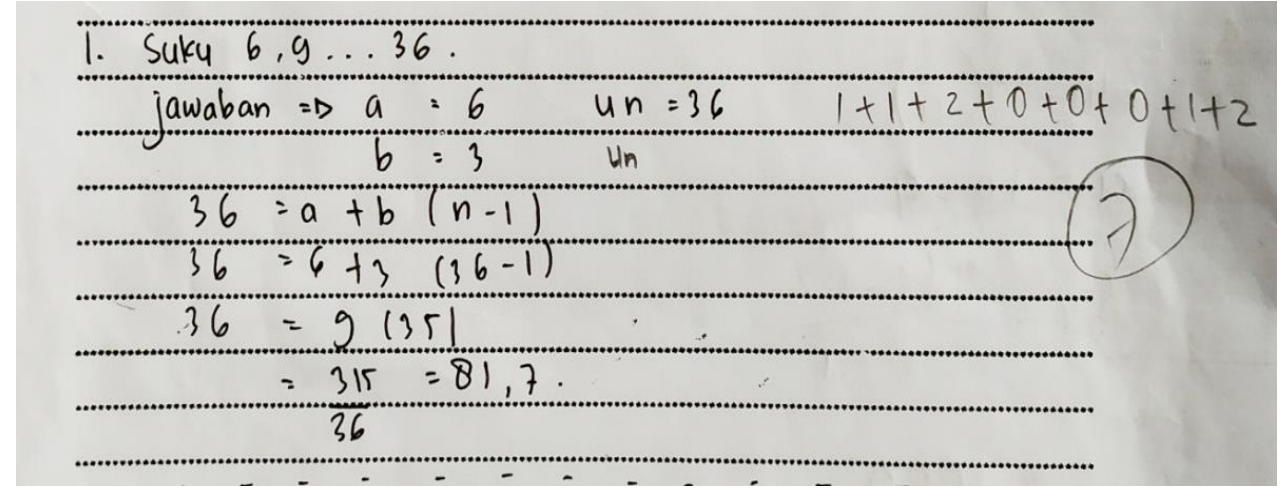

Figure 1. Work student result

The problem in Figure 1 students are asked to find the number of middle tribes, students must first look for Ut. One student's solution to the problem shows that students are still wrong in answering it. Students have a problem distinguishing what is the $\mathrm{n}$-th term and middle term, so the formula or procedure used by students in solving the problem is wrong.

Errors in solving problems are interpreted as deviations from the answers that have been determined truth (Farida, 2015; Putri, 2014). Hudjono said that to solve or obtain, certain rules or laws are needed (Irfan, 2015). The problems are situation when the student has obstacles in their learning process (Widodo, Hidayanti, \& Gunawan, 2019) while an important part of learning mathematics is solving problems (Astutik \& Nuriyatin, 2016). Many problems will slightly affect the problems faced by students. Test questions in the form of description (essay) provide opportunities for students to decipher the answers in accordance with the knowledge they have. Students cannot guess the answers so that problems often arise in the form of essays. Through students' answers in the form of a description (essay), the teacher will be easier to analyze where the location of student errors in solving a given problem. The results of the analysis can be considered improvements in subsequent learning, for example in the use of teaching media.

The problems that arise in the education system in Indonesia are very complex and a common mistake made by students in solving mathematical problems is due to a lack of understanding of concepts and inaccuracy in counting (Perbowo \& Anjarwati, 2017; Rahayu, 2019). Watson and Asikin revealed these errors and categorized based on Watson's category, namely: a) inappropriate data (id); b) Inappropriate procedure (ip); c) Omitted data (od); d) Omitted conclusion (oc); e) Response level conflict (rlc); f) Undirected manipulation (um); g) Skill hierarchy problem (shp); h) Above other (Asikin, 2003; Kasana \& Khotimah, 2019). Watson is a pure behaviorist. He used Pavlov's discovery as a basis for his learning theory. His study of learning is aligned with other sciences that are oriented solely on empirical experience, that is, as far as it can be observed and measured (Nahar, 2016).

First categories is Inappropriate data (id). In this case, students use data that is not quite right in other words incorrectly entering variable values; Second categories is Inappropriate procedure (ip). Students use procedures or methods that are not appropriate, for example using formulas in an inappropriate way; Third categories is oomitted data (od). Missing one or more data from students' responses, thus the solution becomes incorrect; Fourth categories is omitted conclusion (oc). Students show reasons at the right level and then fail to conclude. In solving problems students have not yet reached the final stage of what was asked in the problem; Fifth ctegories is response level conflict (rlc). Students do not understand the form of questions, so what is done is to do simple operations with existing data and then made the final result in a way that is not in accordance with the 
actual concept, or students just simply write the answer without any reason or logical way; Sixth ctegories is undirected manipulation (um). There is a completion of the process of changing from one stage to the next there is something illogical; Seventh ctegories is the skill hierarchy problem (shp). Students cannot solve problems because of a lack of or not visible skills. For example, students can change the basic formula into the requested formula; and last categories is above other (ao). Apart from the seven categories of errors that have been explained above, there is an eighth category where students do not respond to questions. For example, students do not answer the problem at all, or students only write questions back.

\section{METHOD}

This research is a descriptive study with a qualitative approach involving 18 students high schools of a social class in the city of Cirebon, Indonesia. Data collection methods include tests and interviews. Qualitative data analysis was carried out in three stages namely data reduction, data presentation, and conclusion drawing.

The test questions consist of four problem questions that had been validated in advance by researchers using ANATES software. The indicators used in the problem are counting the number of terms of the middle term of an arithmetic sequence, calculating the $\mathrm{n}$-th term of an arithmetic sequence, counting the number of $\mathrm{n}$ first terms of an arithmetic series, and counting the number of the first five terms of a geometric sequence.

\section{RESULTS AND DISCUSSION}

Some research on the Watson's category analysis has been carried out (Kristayulita \& Nurhardiani, 2011; Munawaroh, Rohaeti, \& Aripin, 2018) but they did not discuss the Watson category in the row and series material for social students. Here is the result analysis of student answers accompanied by an interview.

\subsection{Student Answer}

The following are examples of students' answers to each question

\section{Problem number 1}

If arithmetic ranks $6.9, \ldots .36$. Determine how many middle terms! Here is one example of student answers:

1. $\begin{aligned} & a=6 \\ & b=3 \\ & 4 b=36 \\ & 36=a+6(n-1) \\ & 36=6+3(36-1) \\ & 36=9(35) \\ & =315=81+7+0+0+1+2 \\ & 36\end{aligned}$

Figure 2. Work student result for number 1

In this problem, students are asked to find the number of middle syllables. Figure 2 appears that students are still using the formula incorrectly. Students have not been able to distinguish what is an n-th term (Un) and what is the middle term (Ut), it also appears that students are still wrong in entering data $n$, which should be $n$ itself is t. Student mistakes in 
answering question Number 1 based on the Watson category are then analyzed and poured into the following Figure 3.

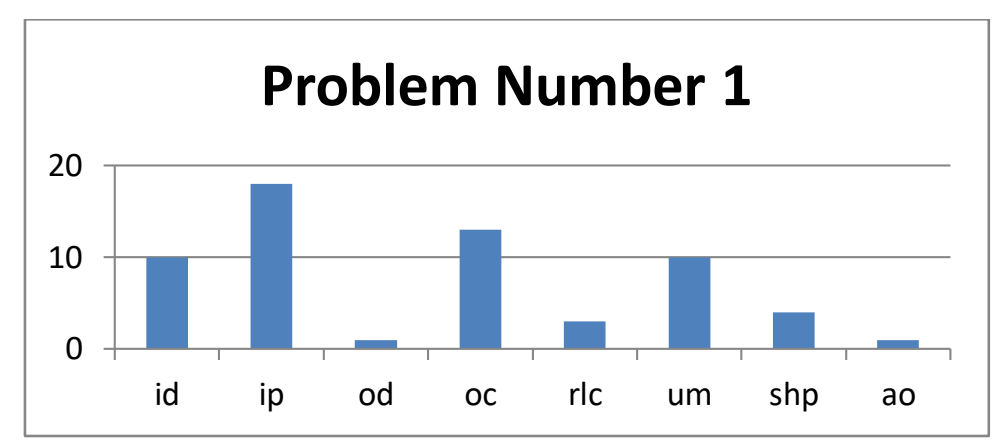

Figure 3. Error results of problem Number 1

Figure 3 shows that the categories of errors made by students varied. There are 18 students who fall into the incorrect procedure category and 13 students who make mistakes in the inference category are missing, for the incorrect procedure category students are still wrong in distinguishing between Ut and Un. From the answers, there are some students who are still wrong in using the formula because they are still using the Un formula in solving problems even though the question asked in the problem is how many middle terms are not the third term. Students are still wrong in using the formula, there are also some students who make mistakes in the category of missing conclusions, namely in solving problems students have not reached the final stage requested in the problem because when determining the student's formula was wrong. The next category is the indirect manipulation category and the problem of skill hierarchy consists of 10 students. In the category of indirect manipulation, students use illogical reasons in solving problems, whereas in the hierarchy category students' skills are still wrong in operating addition and multiplication, when summing and multiplication operations are found students still don't understand which one should be operated first, namely in operation $6+3(36-1)$ some students operate first adding up between $6+3=9$ then continuing to operate $(36-1)=35$ and then the results of both times multiplied by $9(35)=315$ should students first operate contained in brackets and then prioritizing multiplication and finally the sum is $6+3$ (36$1)=6+3(35)=6+105=165$.

\section{Problem number 2}

An arithmetic sequence with $U_{-} 6=11$ and $U_{-} 10=23$. The 11 th term is ..... Here is one example of student answers:

\begin{tabular}{|c|c|c|}
\hline $2 . u_{6}=11$ & $a+5 b=11$ & $a+5 b=11$ \\
\hline $44=23$ & $a+96=23$ & $a+5(3)=11$ \\
\hline$u_{11}=7$ & $-4 b=-12$ & $a+15=11$ \\
\hline \multirow{2}{*}{\multicolumn{2}{|c|}{$b=3$}} & $a=15-11$ \\
\hline & & $a=4$ \\
\hline \multicolumn{3}{|c|}{$u_{n}=a+10 b$} \\
\hline \multicolumn{3}{|c|}{$=4+10(3)$} \\
\hline \multicolumn{3}{|c|}{$=4+30$} \\
\hline $411=$ & & \\
\hline
\end{tabular}

Figure 4. Work student result for number 2 
In problem Number 2 students are asked to find the value of U_11, seen in Figure 4. The answer of one of the students obtained that the student is right in using the formula, the steps taken by the student are correct, that is finding the value of $b$ first then looking for the value of a and new students can look for the value of U_11. The students' answers become wrong because students make changes in the illogical stage when operating the value of a, so that the conclusion becomes wrong. Student mistakes in answering question Number 2 based on the Watson category are then analyzed and presented in the following Figure 5.

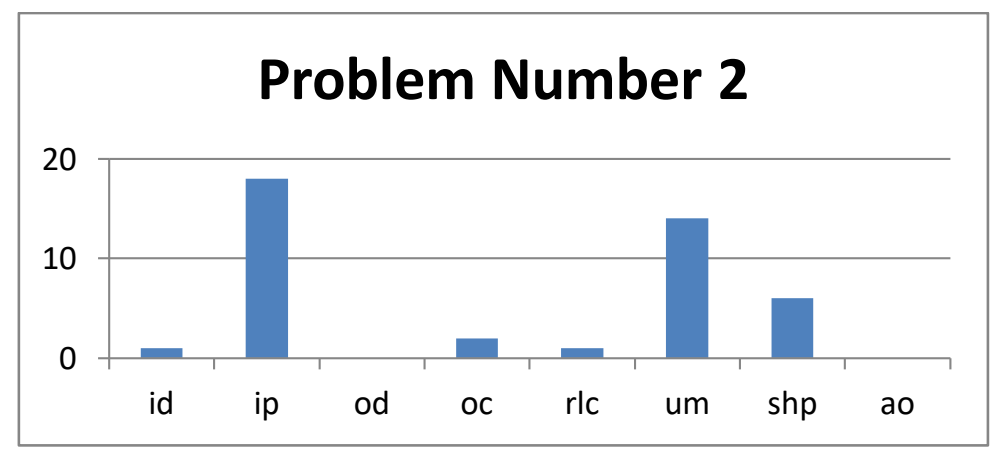

Figure 5. Error results of problem Number 2

Figure 5 it seems very prominent that the ip category errors were made by all students. The mistakes were made by students because students were not quite right in carrying out the completion steps. Some students are right in using the formula that must be used but the procedure in solving problems is not right for students. Students make a mistake at stage $\mathrm{a}+15=11$ they write the results, namely $\mathrm{a}=15-11$ which produces a value $\mathrm{a}=4$, there are also those who answer $\mathrm{a}=11-15$ the result is $\mathrm{a}=-4$, students should answer in the way a $+15=11$ by means of the two segments reduced by 15 to eliminate the value of 15 in the left section, namely $\mathrm{a}+15-15=11-15$, producing $\mathrm{a}=11-15$ produces the value $\mathrm{a}=-4$.

\section{Problem number 3}

A bookstore in the first month sold 50 books, in the second month there were 65 and added 10 more each month. How many books did the store sell for six months? Here is one example of student answers:

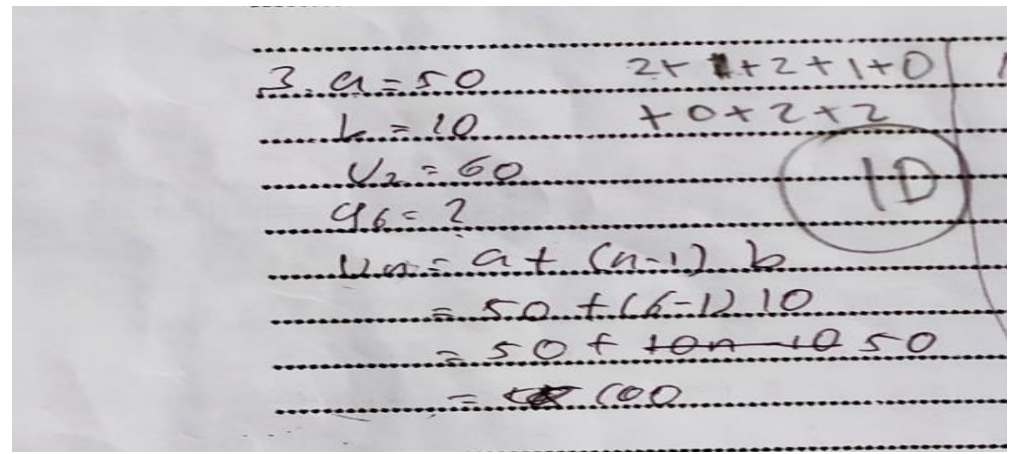

Figure 6. Work student result for number 3

In question Number 3 students are asked to look for the number of books sold for 6 months, namely S_6. Figure 6 it appears that students' answers are not up to looking for 
S_6, but only to the stage of looking for U_6. Student mistakes in answering question Number 3 based on the Watson category are then analyzed and poured into the following Figure 7.

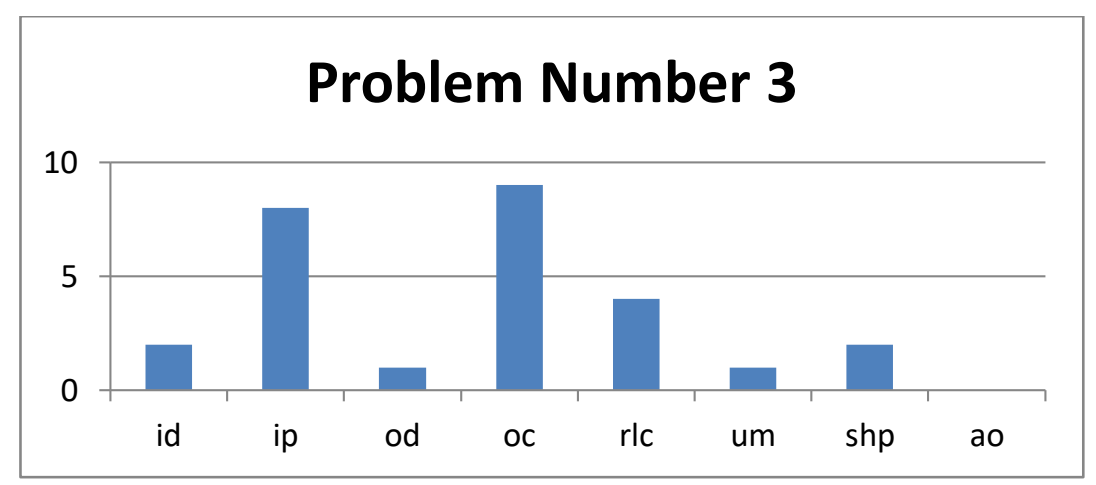

Figure 7. Error results of problem Number 3

Figure 7 it can be seen the error category is $o c$ or the conclusion is missing where some students are still wrong in using the formula. The category error in the conclusion is missing frequently occurs in problem Number 3 because only work up to the stage of finding the value of Un. So that students make a mistake in the category oc that is not reaching the final conclusion requested for the problem because in that problem asking students to find the value of Sn not the value of Un.

\section{Problem number 4}

The third and fifth rows of the geometry are 64 and 4 . If the ratio of the sequences is positive, specify $S \_5$ ! Here is one example of student answers:

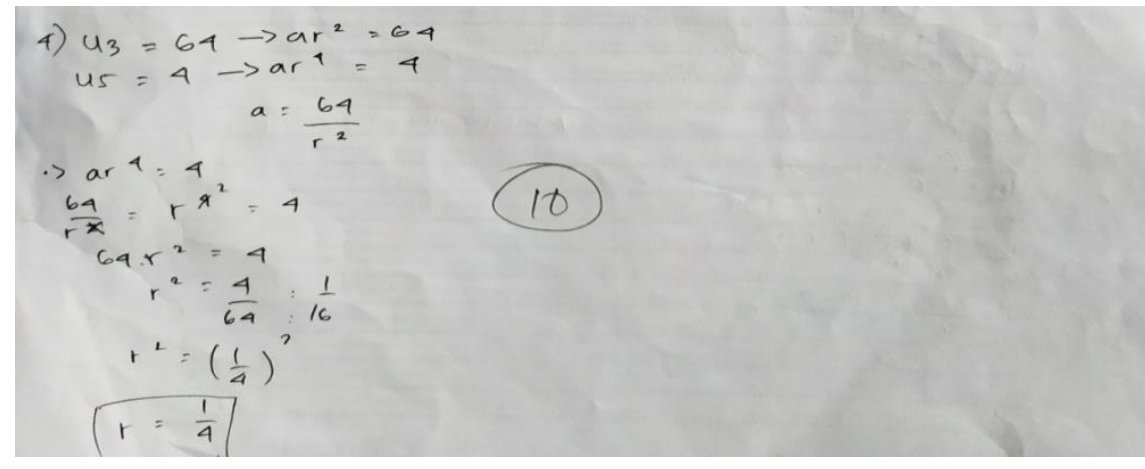

Figure 8. Work student result for number 4

Based on problem Number 4, students are asked to look for S_5 in a geometric sequence. Figure 8 shows that students do not understand the concept of geometry because in these answers' students have not written the formula to be used. Students arrive at the stage of finding the value of r. Student mistakes in answering question Number 4 based on the Watson category are then analyzed and poured into the following Figure 9. 


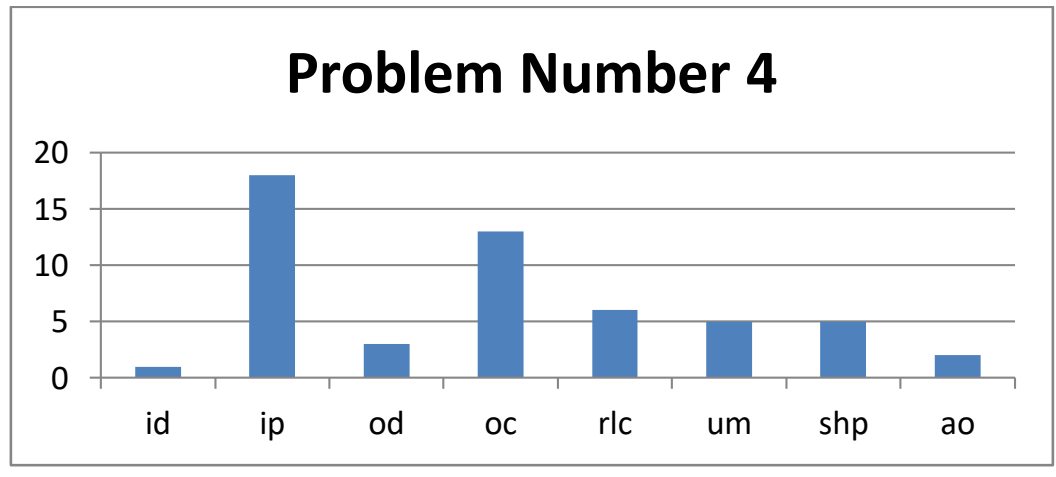

Figure 9. Error results of problem Number 4

Figure 9 show the students who make mistakes. The most prominent is the type of procedure is not right and the type of conclusion is lost. Most students have found the value of $r$ but stopped because they did not know the next procedure to do in answering the questions given. So, students still don't seem to understand the material in this problem. Students cannot perform procedures correctly. Students also make mistakes of type $o c$, ie conclusions are lost, students have not reached the final stage requested for the problem because students also do not perform procedures correctly ie do not know the stage to be done next, the last there 2 students who don't do the questions.

\subsection{Interview result}

The following are the results of interviews based on the results of students' answers that have been identified in accordance with the Watson categories.

\section{Inappropriate data/id}

Based on the results of interviews conducted with S11 students, the researchers found that in the incorrect data category, they were still confused and did not understand the sequence and series question. The student could not distinguish between term $\mathrm{n}$ and term the middle. When entering data into student variables is still wrong, because the students are wrong in determining the formula. So, students are confused to enter a value in the variable.

\section{Inappropriate procedure/ ip}

Based on the results of interviews conducted with S12 students, researchers found that in the category of procedures that were not right. Students working on material and row problems were still wrong in using the formula. Students were still confused about what formula to use. Another factor was because students did not like math lessons because students still consider math lessons difficult. Even students do not pay attention to the teacher when mathematics begins.

\section{Omitted data/od}

Based on the results of interviews conducted with S13 students, researchers found that in the category of missing data errors. Students lacked focus on working on math problems. Students also had negative thoughts in the first place which considered mathematics difficult and could make a headache. 


\section{Omitted conclusion (oc)}

Based on the results of interviews conducted with S14 students, the researchers found that in the category of conclusion was lost. Students in working on the row and series questions were still confused about what steps to do next. Another factor was that students lacked training in doing math problems because they were lazy in counting.

\section{Response level conflict (rlc)}

Based on the results of interviews conducted with S8 students. Researchers found that in the category of conflict the level of response made by students was caused because students were still having difficulty in operating complicated forms. Students immediately guessed the answers because they considered it complicated to continue counting.

\section{Undirected Manipulation Error (um)}

The results of interviews conducted with S5 students, researchers found that the category of manipulation was not directly carried out by students because students were not careful in solving problems, and students were still confused when faced with things like moving positions, confused whether the sign of the operation changed or not.

\section{Skill hierarchy problem (shp)}

The results of the interviews conducted with S6 students. Researchers found that in the category of skills the hierarchy was carried out by students. Students rushed in working on the questions and because at the time of the interview students were aware of these mistakes.

\section{Other Category Error}

The results of the interviews conducted with S4 students. Researchers found that in other categories students did not answer the questions or did not respond to problems at all. Students were hesitant in taking steps to work on the problems and did not like math lessons so that when finding difficult questions, it would be lazy to think.

\section{Percentage of Error Type}

Percentage of types of student errors based on the number of questions and the Watson category, appear in the following Table 1.

Table 1. Percentage of error types

\begin{tabular}{ccccccccc}
\hline Question & $\boldsymbol{I d}$ & $\boldsymbol{I} \boldsymbol{p}$ & $\boldsymbol{O d}$ & $\boldsymbol{O c}$ & $\boldsymbol{r l c}$ & $\boldsymbol{u m}$ & $\boldsymbol{s h} \boldsymbol{p}$ & $\boldsymbol{a o}$ \\
\hline 1 & $16,67 \%$ & $30 \%$ & $1,67 \%$ & $21,67 \%$ & $5 \%$ & $16,67 \%$ & $6,67 \%$ & $1,67 \%$ \\
2 & $2,38 \%$ & $42,86 \%$ & $0 \%$ & $4,76 \%$ & $2,38 \%$ & $33,3 \%$ & $14,28 \%$ & $0 \%$ \\
3 & $7,41 \%$ & $29,63 \%$ & $3,7 \%$ & $33,3 \%$ & $14,8 \%$ & $3,7 \%$ & $7,4 \%$ & $0 \%$ \\
4 & $1,89 \%$ & $33,96 \%$ & $5,66 \%$ & $24,52 \%$ & $26,4 \%$ & $9,43 \%$ & $9,43 \%$ & $3,77 \%$ \\
Whole & $7,69 \%$ & $34,06 \%$ & $2,75 \%$ & $20,33 \%$ & $7,69 \%$ & $16,48 \%$ & $9,34 \%$ & $1,65 \%$ \\
\hline
\end{tabular}


Table 1 for question Number 1 it appears that ip and oc errors are the most mistakes made by students by $30 \%$ and $21.67 \%$, respectively. Students are still mistaking in determining the formula and there are still many students who do not understand. So, the $o c$ error also occurs because at first. The students do not know what formula to use. The students also do not reach the conclusion stage. For the second number, the most mistakes made by students are the um type, which is indirect manipulation. Students are still wrong in changing from one stage to the next stage which is $33.3 \%$. The error is because students are still confused about manipulating because of a lack of practice in working on math problems. The third number, about the number of nth-term students. There are still many errors of ip type, which is an incorrect procedure of $29.63 \%$. Students are still wrong in making the right completion steps. 33, 3\% of students have not reached the final stage that was asked for the problem even though the initial steps used were correct but there were students stopping when completing the questions including. Students forgot the formula, forgot about the steps to be taken next and lacked time in answering. The last for number four, there are also the same errors as other questions. Namely errors in the ip category as much as $33.96 \%$. This shows that students cannot understand the material in the problem. Students do not understand the material. Students are wrong in the procedure which is used which results in an error type oc that is a missing conclusion also occurs the same error made by the students is $26.4 \%$. Students are not able to complete the answers requested on the problem. The percentage of all errors made by students are found in the category of improper procedures and missing conclusions. Students do not understand the material being taught. If students have made mistakes in the category of incorrect procedures, some students will also make mistakes in the category of conclusions lost.

\section{CONCLUSION}

Judging from the overall type of error based on the Watson category there are two categories of errors that are predominantly committed by students, namely the category of incorrect procedures and the category of inferences lost. Based on the results of the study, some solutions that can be done by the teacher to minimize student errors in answering Sequence and Series questions are (1) Develop teaching materials that are followed by guided answers; (2) The teacher should provide more opportunities for students to ask and answer questions on the board; (3) Apperception that is less will adversely affect the success of students in the next material.

\section{ACKNOWLEDGEMENTS}

The authors would like to thank all participants involved in this research. We would also like to thank the Head Master of SMAN 7 Cirebon for supported, giving the opportunity and facilities for this research.

\section{REFERENCES}

Asikin, M. (2003). Pengembangan item tes dan interpretasi respon mahasiswa dalam pembelajaran geometri analit berpandu pada taksonomi solo. Semarang: FMIPA Universitas Negeri Semarang.

Astutik, Y., \& Nuriyatin, S. (2016). Analisis kesalahan siswa dalam menyelesaikan soal cerita aritmatika sosial. Jurnal Pendidikan Matematika, 4(2). 
Farida, N. (2015). Analisis kesalahan siswa SMP kelas VIII dalam menyelesaikan masalah soal cerita matematika. AKSIOMA: Jurnal Program Studi Pendidikan Matematika, 4(2). http://dx.doi.org/10.24127/ajpm.v4i2.306

Irfan, M. (2015). Pemanfaatan gadget dalam pembelajaran matematika serta pengaruhnya pada mahasiswa yang mengalami math-anxiety di universitas sarjanawiyata tamansiswa pada mata kuliah persamaan diferensial. SCIENCE TECH: Jurnal Ilmiah Ilmu Pengetahuan Dan Teknologi, 1(1), 68-76.

Kasana, A. U., \& Khotimah, R. P. (2019). Kesalahan siswa dalam menyelesaikan soal cerita materi program linear berdasarkan kriteria watson pada siswa kelas XI IPA di SMA Negeri 1 Ngemplak. Prosiding Konferensi Nasional Penelitian Matematika dan Pembelajarannya (KNPMP) IV 2019, Prosiding-PM4

Kristayulita, K., \& Nurhardiani, N. (2011). Analisis kesalahan menyelesaikan persamaan diferensial orde-1 pada matakuliah persamaan diferensial dengan panduan kriteria watson. Beta: Jurnal Tadris Matematika, 4(1), 30-52.

Munawaroh, N., Rohaeti, E. E., \& Aripin, U. (2018). Analisis kesalahan siswa berdasarkan kategori kesalahan menurut watson dalam menyelesaikan soal komunikasi matematis siwa SMP. JPMI (Jurnal Pembelajaran Matematika Inovatif), 1(5), 993-1004. http://dx.doi.org/10.22460/jpmi.v1i5.p993-1004

Nahar, N. I. (2016). Penerapan teori belajar behavioristik dalam proses pembelajaran. NUSANTARA: Jurnal Ilmu Pengetahuan Sosial, 1(1).

Perbowo, K. S., \& Anjarwati, R. (2017). analysis of students' learning obstacle on learning invers function material. Infinity Journal, 6(2), 169-176. https://doi.org/10.22460/infinity.v6i2.p169-176

Putri, D. A. K. (2014). Analisis kesalahan siswa dalam menyelesaikan soal yang berhubungan dengan konstruksi statis tertentu berdasarkan taksonomi solo plus pada kelas X TGB SMK Negeri 3 Surabaya. Jurnal Kajian Pendidikan Teknik Bangunan, 3(1), 59-66.

Rahayu, G. (2019). analisis kesalahan siswa SMA dalam menyelesaikan soal trigonometri berbasis kemampuan penalaran menggunakan kategori kesalahan watson. Journal on Education, 1(3), 267-274.

Ratnasari, Y., Rosita, C. D., \& Pramuditya, S. A. (2017). Pengaruh model pembelajaran reciprocal teaching terhadap kemampuan pemahaman dan komunikasi matematis siswa. Procediamath, 1(1).

Widodo, W., Hidayanti, N., \& Gunawan, I. (2019). Pengaruh peran guru terhadap pemecahan barisan dan deret matematika. Jurnal Ilmiah Sains Dan Teknologi, 3(1), 59-77. 